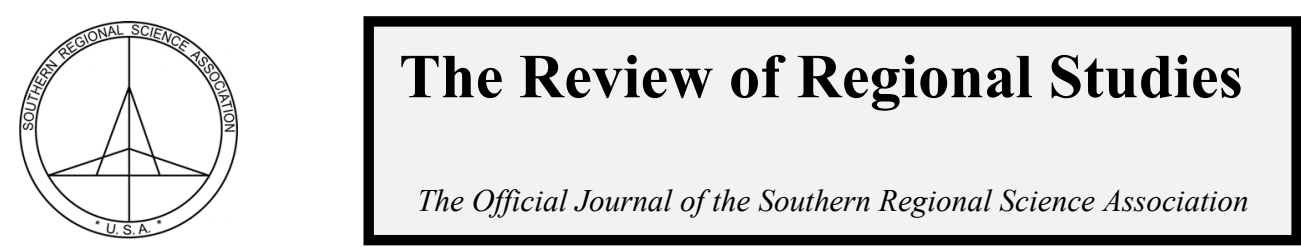

\title{
Unconventional Shale Gas Development and Real Estate Valuation Issues
}

\author{
Clifford A. Lipscomb ${ }^{\mathrm{a}}$, Yongsheng Wang ${ }^{\mathrm{b}}$, and Sarah J. Kilpatrick ${ }^{\mathrm{a}}$ \\ ${ }^{a}$ Greenfield Advisors LLC, Atlanta, GA, and Seattle, WA, USA \\ ${ }^{b}$ Department of Economics, Washington and Jefferson College, USA
}

\begin{abstract}
This article provides an overview of the real estate valuation issues related to unconventional shale gas activities, particularly those related to hydraulic fracturing or "fracking." With the research on this topic in its infancy, we focus more on the valuation issues that can arise as opposed to those that have arisen. Central to this discussion are the factors associated with fracking activities that could alter the existing risk context of real estate valuation in communities and the role that information plays in developing risk perceptions. As current examples of these issues, we discuss some specific legal and regulatory changes that have arisen in Pennsylvania.
\end{abstract}

Keywords: unconventional shale gas, hydraulic fracturing, valuation

JEL Codes: R21, R31, Q38

\section{INTRODUCTION}

Unconventional natural gas is most broadly described as gas that is more difficult or less economical to extract (NaturalGas.org). According to the U.S. Government Accountability Office (2012), unconventional shale gas extraction has become more prevalent since its first use in the 1940s. Hydraulic fracturing or "fracking" is one part of the larger unconventional shale gas development process. Fracking is the process by which natural gas (usually methane) or petroleum is extracted from shale formations when high-pressure fluids are injected into cracks in the rocks, forcing them to open farther. Several activities associated with shale gas development are relatively more permanent (pipelines, roads and related infrastructure, pad area, any chemicals remaining in the groundwater or soil, gas seepage into drinking water) while others are relatively more temporary (local truck traffic, potential odors, earthquakes). We contend that the more permanent features of unconventional shale gas development are likely to affect property values and that the relatively temporary features are more likely to affect residents' use and enjoyment of the affected real estate.

In addition to physical impacts from direct development, shale gas development leads to new legal and regulatory challenges for real estate valuation. How local, state, and federal governments choose to regulate shale gas development will impact real estate values. These impacts are not trivial to individuals and families for whom real estate is a large value asset. Further, property values vary depending on the type of ownership and with the existing local

Lipscomb is Director of Economic Research in Atlanta, GA 30339, and Kilpatrick is Associate Analyst in Seattle, WA 98121.

Both are with Greenfield Advisors LLC. Wang is Associate Professor of Economics at Washington and Jefferson College,

Washington, PA 15301. Corresponding Author: C. Lipscomb. E-mail: cliff@greenfieldadvisors.com

C) Southern Regional Science Association 2013.

ISSN 1553-0892, 0048-749X (online)

www.srsa.org/rrs 
laws regarding shale gas rights. ${ }^{1}$ Local real estate markets in shale gas development areas include four different groups: those who own both surface and mineral rights, those who own only surface rights, those who own only mineral rights, and those that own neither. Shale gas development affects the value of their properties/rights differently. This paper describes the related issues that affect each group, from property rights to environmental concerns. These issues can be used to guide policy makers toward holistic policy design for legal and regulatory changes or updates.

The organization of the paper is as follows: we first present a brief literature review that discusses traditional real estate valuation methods and how shale gas development activities fit in the general context of property valuation. Second, we discuss the relationship between property value and the property owner's shale gas rights. Third, we present surface estate valuation issues related to direct shale gas development for both residential and commercial properties. Fourth, we present information about legal and regulatory changes and developments in Pennsylvania, due to shale gas development, and their impacts on property valuation. This includes a brief discussion of Pennsylvania's Act 13 and a pending Pennsylvania Supreme Court case on shale gas rights. Finally, we conclude with policy recommendations and potential avenues of future research related to real estate valuation and unconventional gas development.

\section{LITERATURE REVIEW}

Traditionally, the impact of amenities and disamenities on property values has been demonstrated using revealed preference and stated preference approaches. The behavioral process that underlies arguably the most commonly used revealed preference approach, the hedonic price method, was initially set forth by Rosen (1974). As described by Taylor (2008, p. 16-17), if consumer utility is defined over two goods, $Z$ and $X$, where $Z$ represents a housing bundle with characteristics $Z=Z_{1}, Z_{2}, \ldots, Z_{n}$ and $X$ is a composite numeraire good, then consumer $\mathrm{j}$ with $\alpha^{\mathrm{j}}$ demographic characteristics has utility defined by $U^{\mathrm{j}}\left(X, z_{1}, z_{2}, \ldots, z_{n} ; \alpha^{j}\right)$. If we further assume that the consumer purchases only one unit of housing, the budget constraint is given by $\mathrm{y}^{\mathrm{j}}$ $=\mathrm{X}+\mathrm{P}(\mathrm{Z})$. Then, the Lagrangian formulation of the utility maximization model is differentiated with respect to each argument in the utility function as well as the shadow prices to yield the first-order conditions. Rearranging the first-order conditions yields the Marshallian demands, which are used to derive the general indirect utility function $\mathrm{v}[\mathrm{P}(\mathrm{X}), \mathrm{P}(\mathrm{Z}), \mathrm{y}]$. By choosing $X$ and each element of $Z$ so that the marginal rate of substitution conditions are satisfied for each $\mathrm{Z}_{\mathrm{i}}$, the consumer maximizes utility.

The empirical translation of the theory presented above is a hedonic pricing model, which is a revealed preference method that typically expresses the price of a good as a function of the characteristics of a good. Boxall, Chan, and McMillan (2005) found a negative impact on residential property value from proximity to traditional oil and gas facilities. However, as of this writing, there is very little literature on the effects of shale gas development activities on property values. An exception is Gopalakrishnan and Klaiber (2012), whose research used the hedonic pricing method to study the effects of shale gas exploration on property values in Washington County, Pennsylvania. Their results indicated that properties are adversely affected by proximate gas exploration sites/wells and that this effect dissipates with time and distance (the effect seems to disappear at 2 miles from a gas exploration site). One of their more interesting

\footnotetext{
${ }^{1}$ Here, we use "mineral rights" as the general term describing all subsurface rights. It varies from state to state whether natural gas rights and shale gas rights are listed separately.
}

(C) Southern Regional Science Association 2013. 
results was that the effect on property values was worse $(-3.8 \%)$ for properties that had well water as a source of drinking water; if these properties were surrounded by agricultural lands, the effect was even larger $(-7.2 \%)$. While their study provides a variety of results using various econometric models, the overall conclusions indicate that the impact on property values due to gas exploration activities diminishes over time and distance, is larger for properties with well water as their main drinking water source, and is larger for properties near agricultural land, which is likely due to the concern of increased activity on surrounding properties.

Similarly, Muehlenbachs, Spiller, and Timmins (2012) utilize a hedonic model to determine if proximity to both vertical and horizontal gas wells creates a difference in property values through water supply. Their results indicate that property values increased for houses with "piped water" (i.e. public water) due to the positive economic impacts of natural gas wells. However, for those houses with "groundwater" (i.e. private wells) the presence of gas wells created a net decrease in housing values. Their research suggests differences in the consequences of gas wells on housing values that may be associated with the perceived risk of groundwater contamination.

Throupe, Simons, and Huo (2012) conducted contingent valuation surveys in Texas and Florida to test for any risk aversion differences to fracking activities. Contingent valuation (CV) is a stated preference method that is based on survey research. Typically, surveys are used to quantify respondents' willingness-to-pay or willingness-to-accept payments. These authors find that property value diminution will range from 5 to 15 percent in a robust real estate market and up to 25 percent in a weaker market, which is defined as having fewer sales and mortgage foreclosure issues.

The overall effect of shale gas extraction on property values is unknown and what is known is limited. The results of the above studies indicate that shale gas development can change the valuation of the existing real estate. However, a few studies cannot provide definitive answers to questions regarding the complex effects of shale gas development activities on property values. Future research is necessary to analyze the role of the economic impacts of shale gas development such as job creation, increased incomes, or population on real estate valuation. It must be understood that effects are different from, and co-exist with issues associated with environmental concerns, stigma, loss of use and enjoyment, the role of lease and/or royalty payments to owners of subsurface rights. The relationship between real estate valuation and shale gas development relates is further complicated by possible structural change and household migration. We expect these changes in housing demand to manifest differently in rural and urban areas. As such, the next section focuses on the valuation issues related to homeowners' shale gas rights and then discusses implications for both rural and urban areas.

\section{SHALE GAS RIGHTS AND PROPERTY VALUE}

Whether or not a property owner holds the surface and the mineral rights leads to a different market value. Property value is derived from the ownership of real property rights. To understand the impact of shale gas development on property values, we start with understanding the role of shale gas rights as a type of property right. Several issues that we discuss below complicate the relationship between property rights and property value in the shale gas context. First, homeowners may own the surface rights, but not own the mineral rights; this situation is called a split estate. Second, urban and rural residents have different considerations even if they own both the surface and mineral rights. Third, shale gas development is a relative new 
phenomenon. Local and state laws often do not have a specific description about shale gas rights, which makes the situation prone to disputes. The answers to the above issues are closely connected to property valuation at the time of resale, routine appraisal, and local assessment. ${ }^{2}$

According to Jaffe and Louziotis (1996), the most traditional economic models of property ownership identify three categories of property rights:

1) Right of use

2) Right of exclusion

3) Right of transfer

These rights are applicable to what is known as fee simple estate (also known as fee simple interest), which is the "absolute ownership unencumbered by any other interest or estate, subject only to the limitations imposed by the governmental powers of taxation, eminent domain, police power, and escheat" (Appraisal Institute, 2010). By contrast, the leasehold interest is "the tenant's possessory interest created by a lease" (Ibid.).

A typical homeowner has a fee simple interest, but with shale gas development leases these rights may become encumbered. For example, a property owner granting a shale gas development lease would share the right of use with the shale gas development company and associated parties; in doing so, they lose the right to exclude these parties from their property. In addition, they may lose the right to transfer (or sell) the property due to these leases, or they may only be able transfer (or sell) certain parts of the property depending on the various terms of the contract/lease. Further, current owners may find it difficult for potential buyers to obtain a mortgage if shale gas development leases are in place. We discuss this topic in more depth in a later section on mortgageability.

\subsection{Land versus Mineral Rights}

Understanding the traditional relationship between land and mineral rights is the key to understanding the unconventional shale gas rights attached to a property. In some states, property owners with fee simple interest can own the land rights, mineral rights, air rights, and even water rights to a property. In other states, an owner has the rights to only parts of these various media, and the municipality, for instance, owns the rest. It is important for property owners and policymakers to understand what can and cannot be owned and/or leased. Typically, the more rights a property owner owns the higher the value of the property. No matter how different the local mineral right regulations are, shale gas rights are a type of subsurface right.

One important note regarding land and mineral rights is that research indicates that underground changes (e.g. underground contaminants) have a direct and measurable impact on both fee simple values as well as the value of the surface rights taken alone. As a result, even though a lease or easement may only grant subsurface rights, an environmental condition in the subsurface may actually impair the value of the entire property. Lipscomb and Kimball (2012) provided an overview of the valuation issues and appraisal processes used to value subsurface rights. They note that appraisers must be careful to indicate what interests are being appraised, whether that be the "mineral estate" (the subsurface rights) or the "surface estate" (surface rights). The market value of the subsurface and surface rights cannot simply be added together

\footnotetext{
${ }^{2}$ Homeowners can trade mineral rights and surface rights separately if they own both of them.
} 
to create a total value. Additional complexity arises because the laws and regulations regarding these different interests vary by state.

Generally, most states in the U.S. adopt common law, which considers mineral rights as the dominant estate. Thus, homeowners, especially those who only have surface rights, cannot stop mineral right owners from exercising the right to drill on their properties. Homeowner compensation for access varies across states. For example, according to the Pennsylvania Department of Environmental Protection (2010), the Commonwealth of Pennsylvania requires surface owners to provide "reasonable access for development and production" for mineral right owners. For surface right owners, activities such as legal consultation, pre-drill documentation, and well-site negotiation with drillers can be costly and time consuming; but they serve a vital purpose in protecting property rights pre/post lease. This may be the main way that homeowners can protect their property interests if related public policies gravitate toward more favorable policies for drilling companies.

\subsection{Rural versus Urban Considerations}

The valuation issues associated with shale gas development vary across rural and urban areas. Homeowners and prospective buyers of properties from rural and urban areas have different considerations of shale gas rights that are related to the usage and value of property.

Drilling on rural lands potentially poses the risk of making the lands less accessible for livestock and agriculture, and makes agricultural land planning for an entire property more difficult. At the time of a resale, the presence of gas wells on large rural tracts may restrict a property owner's ability to subdivide his/her property if drilling pads, containment ponds, access roads, and other building structures occupy certain portions of the property. Property value may suffer from decreased accessibility, difficulty of subdividing, and loss of acreage. ${ }^{3}$ Local municipalities rarely reassess a property after a gas well is drilled unless property owners file a request to dispute the existing property assessment. In rural areas, homeowners rely on well water more often than municipal water, and the effects on property values from shale gas development activities may be stronger (e.g., Gopalakrishnan and Klaiber, 2012). For rural residents without access to municipal water, the quality of well water is essential for daily living and is a key driver of property value. Any actual risk or perceived risk related to water can affect property value. ${ }^{4}$

A final concern for rural residents who have mineral rights is that they may face restricted choices if they want to avoid shale gas development. Many oil and natural gas rich states have certain kinds of oil and gas conservation laws that describe the specific conditions for compulsory pooling. ${ }^{5}$ This is where neighboring owners of potential oil and gas deposits join their lands together for exploration either voluntarily or under compulsory orders from state or local governments. If the pooling is voluntary, we assume that property owners are rational and are seeking to maximize their economic benefits. However, if pooling is mandatory, the law is

\footnotetext{
${ }^{3}$ According to Range Resources, one of the largest Marcellus Shale gas companies, it can take from several months to two years to drill a well. http://www.myrangeresources.com/Drilling/learn_drilling.aspx (retrieved on November 7, 2012)

${ }^{4}$ Fraser (2012) shows that 82.6 percent of residents from 31 shale drilling counties across Pennsylvania, Ohio, West Virginia, and Maryland think there is some environmental risk from Marcellus Shale development: http://www.pittsburghtoday.org/specialreports/MarcellusShaleWashingtonCounty.pdf (retrieved on November 22, 2012).

${ }^{5}$ Please refer to the following links of pooling of properties for oil and gas production from Pennsylvania and Michigan for further details: http://www.portal.state.pa.us/portal/server.pt/community/marcellus_shale/20296; http://www.michigan.gov/documents/deq/ogs-oilandgas-pooling_257974_7.pdf.
}

(C) Southern Regional Science Association 2013. 
designed largely from the perspective of mineral rights owners and may not fully protect (surface) property values. This is an area where property values and potential environmental risks should be evaluated in policy creation and design.

Unconventional shale gas development in urban areas might affect property values, but is different from shale gas development in rural areas for several reasons. In urban areas, houses are more densely located. Drilling in urbanized communities and near public facilities brings additional uncertainty for homebuyers and for drilling companies. Urban home sites are typically much smaller than sites in rural areas. This suggests that the percentage of urban land required for shale gas development, assuming the footprint of a shale gas well site is held constant, is higher than the percentage of rural land required for shale gas development. Cady (2009), suggests that, for urban homeowners who control both the surface and mineral rights, the perceived costs of having gas wells in their backyards are greater than the perceived benefits (royalties).

As a side note, average annual royalty payments can be on a per-acre or per-well basis. On a per-acre basis, royalty payments range from several hundred to several thousand dollars per acre in early years of drilling, and decreases over time following the decline of well production. ${ }^{6}$ Payments vary based on the size of a property and the market price of natural gas. For example, on a per-well basis, Encana, a Canadian company that operates 140 gas wells near Pavillion, Wyoming, pays property owners $\$ 1,321$ on average for each year of access to their land (Drajem, 2012).

Urban drilling has some associated environmental impacts; these include the disposal of waste water, air pollution, noise, and fresh water usage (Cady, 2009). In the later section on legal and regulatory issues, we will discuss more about urban drilling issues based on the highly debated Pennsylvania Act 13.

From the above discussions, it seems that owners of large land parcels who control both the surface and mineral rights may benefit the most from shale gas development. Of course, the extent of shale gas development "winners" and "losers" has to be determined on a case-by-case basis and depends on how much surface activity interruption occurs due to unconventional shale gas development, royalty amounts, and fiscal policy pursued by state and local governments.

\section{DIRECT SHALE GAS DEVELOPMENT AND VALUATION OF THE SURFACE ESTATE}

In a previous section we discussed shale gas rights and royalty payments. In this section we focus on the potential impacts of direct shale gas development on valuation of the surface estate. We briefly mentioned this issue in the last section as it pertains to urban and rural homeowners. In this section we discuss the potential positive and negative impacts of direct shale gas development and how these impacts may affect commercial (income-producing) properties.

From a positive perspective, shale gas development may stimulate demand in local housing markets. According to a joint survey released in November 2012 from the University of Pittsburgh and Pittsburgh TODAY for 31 counties with Marcellus Shale gas development across

\footnotetext{
6 Links to royalty calculators for Pennsylvania and Texas are: http://gomarcellusshale.com/royalty-calculator and http://southlakedrillingfacts.com/SouthlakeDrillingFacts.com/Facts_about_Royalties.html (retrieved on November 7, 2012).
}

(C) Southern Regional Science Association 2013. 
Pennsylvania, Ohio, West Virginia, and Maryland, fully 90 percent of respondents believe that, to certain degree, "Marcellus Shale represents an economic opportunity;" and 74.9 percent residents either support or do not oppose shale gas extraction. It is uncertain whether the anticipated opportunities will occur and how local real estate markets will be influenced. If economic growth promotes population growth in the local areas as in-migration exceeds outmigration, it is expected, ceteris paribus, that increases in housing demand drive up regional housing values (Fraser, 2012). Likewise, anecdotal evidence suggests that property values may reflect capitalization of the subsurface rights/interests.

Alternatively, property value diminution may result, for example, from a violation of the bundle of rights as a result of environmental contamination or due to stigma from how real estate market participants perceive the real estate risks associated with shale gas development, especially for properties close to the shale gas development sites. For an overview of perceived risk (a type of stigma) as it relates to property values, see McCluskey and Rausser (2001). For an overview of stigma as it relates to property values, see Mundy (1992).

Other factors in property value diminution may occur if the habitability decreases (also related to use and enjoyment of that property); the ability to finance, refinance, or mortgage the property decreases; the ability to rent a property decreases; the risk perceptions of property owners change; or the risk of physical endangerment increases (also related to use and enjoyment). With the environmental uncertainties associated with unconventional shale gas activities, each of these outcomes is possible. ${ }^{7}$ Appraisers measure the market value of real estate, as well as the diminution in value, using comparable market data. If reliable market data are not available, an alternative way to measure the changes to marketability, habitability, financing, and perceived and actual risks is to use survey research. Lipscomb (2011) provides an example of the use of survey research to measure the potential prospective impacts of a new biomass facility on surrounding property values. Certainly this kind of survey research would be applicable to a broader regional scale (instead of the local level) if theory suggests that the impact of unconventional shale gas activities would be capitalized into the regional housing market.

Environmental risk is one of the major factors that concerns local residents and influences property values. According to the same joint survey noted above, 82.6 percent of residents believe that there is some environmental risk from shale gas development. Chemicals involved in the shale gas development process, such as the fracking fluid itself, benzene, and methane, may enter the environment through various media. Also, noise from the truck traffic associated with shale gas development activities may be related to one's use and enjoyment of their property. Next we discuss how the environmental risks potentially related to shale gas development affect property value through four media: noise, air, water, and soil.

\subsection{Noise}

Shale gas development exploration and drilling often comes with increased activity (and noise) in small geographic areas. Increases in noise can cause areas that are not typically

\footnotetext{
7 As of this writing, we are aware of at least one situation that may involve nearby fracking activities near a private home in Texas that resulted in the death of the owners' entire cattle herd and health impact on family members (Lisa Parr and Robert Parr v. Aruba Petroleum, Inc. et al., Cause No. CC-11-01650-E, In the County Court at Law No. 5, Dallas County, Texas). We are also aware that in December 2011 the U.S. Environmental Protection Agency issued a preliminary report citing the Pavillion, Wyoming area as the only place in the nation where fracking activities are causing water contamination. These kinds of situations likely will not be noticed in regional hedonic property value models.
} 
proximate to industrial activities and associated noise to be disturbed. Rural areas may be affected even more from increased noise impacts due to the already quiet natural surroundings and low background noise levels. Various studies have indicated that noise from traffic negatively affects property values (e.g., Wilhelmsson, 2000).

\subsection{Air}

Environmental impacts to air may occur due to shale gas development activities. Various news articles in recent years have indicated that dust (and whatever may be in that dust) as well as methane can move through the air near shale gas development sites. Further, diesel fumes from drilling engines and fracking pumps have been noted in various other news media as well as fumes from increased truck traffic (and associated noise). According to a June 12, 2012 article in The New York Times the World Health Organization declared that diesel fumes cause lung cancer, adding it to its list of carcinogens (McNeil, 2012).

With a variety of chemicals used in shale gas development activities, there could be other concerns related to air exposure, but these chemicals vary by site and by company and are not monitored in most states at this time. Regulations are slowly changing and various states require disclosures of these chemicals as well as the amounts used.

\subsection{Water}

According to Armstrong (2011), at least two potential environmental risks result from shale gas development: the additional demand on water resources required to perform hydraulic fracturing and the "potential release of hydraulic fracturing chemicals into the environment." In a recent Appraisal Journal article (Huso, 2012), one appraiser interviewed for the article indicated that "land without water has no value." His concern stemmed from an actual lack of water supply due to vast amounts of water being used in the fracking process. Current water supplies and the water required for shale gas development activities could become a real issue, which could affect the value of leases on lands used for shale gas development activities.

Abdalla et al. (2012) provided a description of the paths that shale gas development waters take and indicated that 60 to 90 percent of fracking fluids may remain below the surface. With the various components of fracking fluids as well as the naturally occurring elements (for instance methane) that are relocated due to shale gas development, groundwater can potentially be affected. From a valuation perspective, water quality affects property values.

Lunz (1989) noted that owners with contaminated groundwater underlying their properties have had their bundle of rights diminished. As a result, the properties lose both their preservation and value creation potential. For owners of properties with groundwater contamination, the bundle of rights is reduced to the single right of owner occupancy. Given some of the research on unconventional shale gas development and property values (e.g., Gopalakrishnan and Klaiber, 2012), it is not surprising that these effects are exacerbated if the primary source of water is a private well.

\subsection{Soil}

For soil, spills from "flowback" water can potentially cause both surface and subsurface soil contamination, which some experts indicate may be slightly radioactive according to Bernstein, Kinnaman, and $\mathrm{Wu}$ (2013). It is possible that environmentally affected soil correlates to property value diminution, though the impact likely will vary by contaminant, exposure pathways, and quantity (though quantity may not be relevant in all cases).

(C) Southern Regional Science Association 2013. 


\subsection{Environmental Concerns for Income-Producing Properties}

Up to this point, we have focused on environmental contamination media and how they may impact residential properties. But, it is possible that income-producing properties may be impacted by shale gas development. Kilpatrick and Mundy (2003) discussed four factors that affect the value of income-producing property due to contamination:

1. Reduction in net operating income. This can be due to increased vacancy rates when finding a tenant to lease the space or finding a replacement tenant due to turnover takes longer than typical (assuming no contamination or stigma). With an increase in vacancy rates, an increase in property maintenance expenses typically follows. Typical passthrough charges to the tenant, such as utilities and yard maintenance, would be the responsibility of the landlord during periods of vacancy. Increased vacancy rates and maintenance expenses reduce net operating income.

2. Actual cost-to-cure. The costs for any on-site remediation could be borne by the landlord/owner, further reducing net operating income.

3. Ongoing increases in maintenance.

4. Stigma, which frequently results in increased capitalization (cap) rates, which are highly sensitive to risk or risk perception.

In Mundy's model, slight increases in cap rates can overwhelm the other three factors as a component of value diminution or loss. The author concluded that, in some circumstances, stigma effects are actually the greater portion of value losses to income-producing property owners. Therefore, commercial (income-producing) properties share some similar issues with residential properties (e.g. cost-to-cure, maintenance, and stigma) with respect to shale gas development that must be considered in discussion of public policy.

\section{LEGAL AND REGULATORY ISSUES AND PROPERTY VALUE}

As we have discussed, unconventional shale gas development can affect property values across property types (e.g. residential and commercial). Two of the major concerns related to property values and shale gas development are mortgageability and insurance. We present these items first, followed by a discussion of the relationship between legal and regulatory issues related to shale gas development and property values. As a case study, we present a brief discussion of Pennsylvania's Act 13 and a pending Pennsylvania Supreme Court case on shale gas rights.

\subsection{Mortgageability Concerns}

Mortgageability concerns stem from the potential environmental hazards and risks that may occur from shale gas development activities. If environmental contamination or risk is present (e.g. if drilling activities are present on a property), some banks will not originate mortgage loans on those residential properties. In a New York Bar Association article, Radow (2011) indicated that Wells Fargo is one of the banks that will not originate a loan on a residential property with drilling activities. For homeowners hoping to sell their home in the future, there is cause for concern that shale gas development activity may affect their ability to sell due to a potential buyer's inability to originate a mortgage on the property. Perhaps a greater concern is the situation of improper shale gas development activities, which would have its own set of environmental concerns. In essence, having drilling activities on one's property could 
affect the mortgageability of that property and should be researched in advance of signing any type subsurface lease. The compensation outlined in the lease may not be greater than or equal to the diminution in value of the property.

At the federal level, the Selling Guide: Fannie Mae Single Family (2009) provides some guidance on conditions that Fannie Mae considers unacceptable for federally subsidized loans. Also, the U.S. Department of Housing and Urban Development (U.S. HUD) has at least two documents that provide valuation guidelines and details on unacceptable sites and hazards: the Valuation Analysis for Single Family One- to Four-Unit Dwellings (U.S. HUD, 2007) and the Multi-Family Accelerated Processing (U.S. HUD, 2009) guide. U.S. HUD's environmental requirements include that the lender in a potential transaction must provide an environmental report that identifies any significant environmental issues to U.S. HUD. This environmental report may include a U.S. Environmental Protection Agency Phase I (an administrative review) and/or Phase II (which involves environmental sampling) site assessment.

The lack of mortgageability of a property is likely to be of concern to single-family real estate values. If lenders are reluctant to lend money to potential buyers, then housing transactions may be delayed or may not consummate at all. This would affect all parties (e.g. buyers, sellers, agents, and brokers) involved in real estate transactions. Certainly there can be a stigma associated with properties on which lenders are not willing to lend. As Robinson and Lucas (1998) suggest, stigma may result from "mortgage discrimination."

\subsection{Insurance Concerns}

Another concern related to real estate valuation is the lack of insurance coverage for any potential claims that might result from improper shale gas development activities on or near one's property. On July 13, 2012, Nationwide Mutual Insurance Company (2012) issued a press release that said the company did not have a comfort level with the unique risks associated with shale gas development and that they could not insure against problems from fracking activities for a reasonable price. This decision by Nationwide suggests that property owners should consult with their insurance company and possibly an attorney to determine the possible outcomes in case of an adverse event related to shale gas development activities. Since a property owner may not be able to insure against potential damage from shale gas development, s/he could potentially include a clause in the lease agreement requiring the lessee to return the property to its previous condition when the drilling activities are completed. Insurance coverage limitations or increased premiums could affect the amount that homebuyers are able to pay for housing, as overall households costs could increase. From a regional perspective, this is not dissimilar from the change in insurance carriers' coverage in Florida after a particularly damaging series of hurricanes in that state. It will be interesting to see if similar withdrawals of coverage occur as a result of shale gas development activities.

\subsection{Act 13 and the Dunham Rule: The Case of Pennsylvania}

Shale gas rich areas are experiencing significant changes in certain legal requirements to either better accommodate or monitor the development of shale gas. Protecting local residents and their properties is one of the motivations for these changes, which will have major impacts on real estate markets generally as well as individual properties. If legal requirements are too strict, then shale gas development may be stifled and property values will experience no impact, ceteris paribus. If legal requirements have a lack of specificity, then this will cause confusion, disputes, and even abuse of the legal and regulatory system. We use Pennsylvania Act 13 and a 
pending Pennsylvania Supreme Court case as examples to demonstrate the depth of changes, the degree of potential disputes, and eventually the strong impact on property values.

The Marcellus Shale formation covers about 60 percent of Pennsylvania. The boom in shale gas development activities comes with new regulations and controversies. Act 13 of 2012 is a new Pennsylvania statute that regulates conventional and unconventional oil and gas development (House Bill No. 1950). It amends the Pennsylvania Oil and Gas Act of 1984. The Act consists of six major chapters that address different aspects of the regulatory issues. These include:

1) establishment of an "unconventional gas well fee" to mitigate uncompensated impacts to communities by natural gas development

2) establishment of an "oil and gas lease fund"

3) establishment of a "natural gas energy development program"

4) enforcement procedures to protect health and safety of related parties and public and private interests related to the environment and natural resources

5) "local ordinances relating to oil and gas operation," and

6) "responsibility for fee."

One of the controversial parts of Act 13 is the chapter related to local ordinances. It requires the "uniformity of local ordinances," which means that "all local ordinances regulating oil and gas operations" have to allow for the "reasonable development of oil and gas resources." The Act makes it potentially possible to drill oil and gas wells anywhere in local communities in Pennsylvania, no matter what the prior zoning ordinances stipulate. Several municipalities, together with other entities, filed a lawsuit in the Commonwealth Court challenging this provision on the grounds that its requirement of uniformity divests municipalities of the ability to use their local zoning authority to protect their communities. In Robinson Township, et al. v. Commonwealth of Pennsylvania Public Utility Commission, et al., the Commonwealth Court issued an opinion on July 26, 2012, voiding the relevant provisions of Act 13. The plaintiff agencies filed an appeal with the Pennsylvania Supreme Court. The case status is pending. The final ruling of this case is likely to have a profound effect on oil and gas development and affect property values in Pennsylvania.

Besides the controversial regulatory statute, the Pennsylvania Supreme Court is reviewing another case related to complicated mineral rights that may shake the foundations of the historic Dunham rule, which originated from Dunham v. Kirkpatrick, 101 Pa. 36 (1882). According to the Dunham rule, without specific mention, the reservations of minerals stated in a deed do not include oil and natural gas. In other words, mineral rights owners may not own the rights to oil and natural gas. However, in the case of Butlers v. Powers, the lower court ruling based on the Dunham rule was reversed by the Pennsylvania Superior Court. It focused on the "unconventional" nature of Marcellus Shale gas that is locked in the rock formation and different from traditional natural gas. The case was appealed to the Pennsylvania Supreme Court. In April 2012, the Pennsylvania Supreme Court agreed to take the case, which is currently pending. If the Dunham rule cannot be applied to Marcellus Shale, shale gas can be treated like coal bed gas, which belongs to the mineral rights owner and would complicate the existing and future shale gas leases. Needless to say, the property valuation issues related to these leases would be complicated.

(C) Southern Regional Science Association 2013. 


\subsection{General Policy Issues}

Zoning has been used as a method of preserving property values. Industrial activities typically are not allowed in residential or even rural zones. As such, industrial properties require their own zoning under listings such as light or heavy industrial. Shale gas development is different because of the overlapping jurisdictions between states and local municipalities. Some states (e.g., New York and Pennsylvania) have state laws focusing on the regulation of oil and gas development and local laws focusing on land use. In the case of New York and Pennsylvania, both have state laws with provisions that supersede the local laws, which create difficulty for local zoning laws to work as intended when contradictions arise. A consistent legal framework in a state is crucial in order to have effective policies on shale gas development that create more certainty in local real estate markets.

It is common, in shale gas development areas, to find properties in a non-drilling township that experience impacts from activities taking place in an adjacent or nearby township that allows drilling. The possibility of externalities across communities also poses challenges for property valuation. Furthermore, according to the Appraisal Institute, appraisers usually use the sales comparison approach for residential property valuation, which requires data from prior transactions of similar properties. Since shale gas development is a relatively new consideration for appraisers generally, the techniques for making adjustments for "external obsolescence" in a non-drilling community due to the proximity to drilling communities have not been fully developed and codified. This adds another layer of complexity to property valuation in regions with shale gas development.

Policymakers must be aware of the potential spillovers that may occur in nearby communities if a shale gas development site is approved. An "external factors" consideration in the site approval process could be included, which would require shale gas developers to provide data to policy makers on the type and magnitude of potential spillovers to other communities, such as increased truck traffic (road infrastructure), increased water usage (aquifer supply), and increased dust (air quality). Further, additional scientific research could inform policies that specify a "safe" distance to the nearest drinking water source, or perhaps a "safe" distance from a residential area.

\section{CONCLUSIONS}

We have discussed a range of possible impacts on property values that may be associated with shale gas development. With the research on this topic in its infancy, the scholarly community will continue to learn as time passes. Particularly important will be the science that is needed to indicate an appropriate distance a shale gas well should be, for example, from residential properties and drinking water sources (such as rivers and private wells). It is necessary to obtain objectively measurable estimates of the environmental impacts. Then, once the scientific evidence has been determined, it is necessary to express these impacts on real estate valuation. Broadly speaking, changes in real estate valuation can be measured using revealed preference (e.g. hedonic pricing) or stated preference (e.g. contingent valuation) methods. Revealed preference methods are based on rents, incomes, and prices observed in the marketplace; stated preference methods are based on survey research, which can be used to quantify respondents' willingness-to-pay or willingness-to-accept payments in contingent valuation $(\mathrm{CV})$ scenarios.

(C) Southern Regional Science Association 2013. 
The role of information about the science of shale gas development activities and how that information is used to create perceptions in the marketplace is critical. Sanders (1996) noted that geotechnical issues are among the most complex for market participants to understand. As a result, markets may be slow or inefficient to incorporate information about shale gas development into sales prices. In situations such as this, "stated preference" methods such as contingent valuation are often preferred over other "revealed preference" valuation methods because the former often provide more salient information about impacts to property values instead of sales prices. That is why we might expect there to be situations where the value impacts for individual properties may differ from the general average results one might find from regional econometric models.

\section{REFERENCES}

Abdalla, Charles, Joy Drohan, Brian Rham, Jeffery Jaquet, John Becker, Alan Collins, H. Allen Klaiber, Gregory Poe, and Deb Grantham. (2012) Water's Journey Through the Shale Gas Drilling and Production Processes in the Mid-Atlantic Region. Pennsylvania State University in conjunction with various parties.

Appraisal Institute. (2010) The Dictionary of Real Estate Appraisal, 5th ed. Appraisal Institute: Chicago.

Armstrong, Matt. (2011) "The Process and Policy Implications of EPA's Hydraulic Fracturing Study," Trends, 42, 1-14.

Bernstein, Paula, Thomas C. Kinnaman, and Mengqi Wu. (2013) "Estimating Willingness to Pay for River Amenities and Safety Measures Associated with Shale Gas Extraction," Eastern Economics Journal, 39, 28-44.

Boxall, Peter C., Wing H. Chan, and Melville L. McMillan. (2005) "The Impact of Oil and Natural Gas Facilities on Rural Residential Property Values: A Spatial Hedonic Analysis," Resource and Energy Economics, 27, 248-269.

Butler v. Powers. (Docket Number: 27 MAP 2012). Last accessed in January 2013 at:http://www.fulbright.com/e_templates/crd/publications/120405Butler\%20Docket.pdf.

Cady, R. Marcus, II. (2009) "Drilling into the Issues: A Critical Analysis of Urban Drilling's Legal, Environmental, and Regulatory Implications," Texas Wesleyan Law Review, 93112.

Drajem, Mark. (2012) "Fracking Is Safe - Except in Wyoming," Bloomberg Businessweek, September 6, 35-36.

Dunham v. Kirkpatrick, 101 Pa. 36 (1882). Agricultural Law Resource and Reference Center at Penn State University. (2012) last accessed in January 2013 at http://law.psu.edu/academics/research_centers/agricultural_law_center/resource_areas/m arcellus_shale/case_law/pa_supreme_court.

Fannie Mae. (2009) Selling Guide: Fannie Mae Single Family. Last accessed in January 2013 at https:/www.efanniemae.com/sf/guides/ssg/sgpdf.jsp.

Fraser, Jeffery. (2012) 'Marcellus Shale Brief,' University of Pittsburgh and PittsburghTODAY Survey, November 19. Last accessed in January 2013 at http://www.pittsburghtoday.org/special_marcellus_brief.html.

(C) Southern Regional Science Association 2013. 
Gopalakrishnan, Sathya, and H. Allen Klaiber. (2012) "Is the Shale Boom a Bust for Nearby Residents? Evidence from Housing Values in Pennsylvania." The Ohio State University Working Paper, accessed in January 2013 at http://papers.ssrn.com/sol3/papers.cfm?abstract_id=2117932.

House Bill No. 1950. Last accessed in January 2013 at http://www.legis.state.pa.us/CFDOCS /Legis/PN/Public/btCheck.cfm?txtType=PDF\&sessYr=2011\&sessInd=0\&billBody $=$ H\&billTyp $=\mathrm{B} \&$ billNbr $=1950 \& \mathrm{pn}=3048$.

Huso, Deborah R. (2012) "Fracking Up," Valuation Magazine (First Quarter 2012), 17(1), 1620. Last accessed on January 2013 at http://www.valuation-digital.com/valuation/20121stQ\#pg16.

Jaffe, Austin J., and Demetrios Louziotis Jr. (1996) "Property Rights and Economic Efficiency: A Survey of Institutional Factors," Journal of Real Estate Literature, 4, 137-159.

Kilpatrick, John A., and Bill Mundy. (2003) "Appraisal of Contaminated Property in the United States," Journal of the Japan Real Estate Institute, 25-32.

Lipscomb, Clifford A. (2011) "Using contingent valuation to measure property value impacts," Journal of Property Investment and Finance, 29, 448-459.

Lipscomb, Joseph B., and J.R. Kimball. (2012) "The Effects of Mineral Interests on Land Appraisal in Shale Gas Regions," Appraisal Journal. 80, 318-329.

Lisa Parr and Robert Parr v. Aruba Petroleum, Inc. et al., Cause No. CC-11-01650-E, In the County Court at Law No. 5, Dallas County, Texas.

Lunz, Robert. (1989) "Groundwater Contamination and Real Estate Value: How What Is Below Affects What Is Above," U.S. Water News, 6, 13.

McCluskey, Jill J. and Gordon C. Rausser. (2001) "Estimation of Perceived Risk and Its Effect on Property Values," Land Economics, 77, 42-55.

McNeil, Donald G. (2012) "W.H.O. Declares Diesel Fumes Cause Lung Cancer," New York Times. June 12, 2012.

Muehlenbachs, Lucija, Elisheba Spiller, and Christopher Timmins. (2012) "Shale Gas Development and Property Value: Difference across Drinking Water Sources," National Bureau of Economic Research Working paper 18390. Last accessed in January 2013 at http://www.nber.org/papers/w18390.

Mundy, Bill. (1992) "Stigma and Value,” Appraisal Journal, 60, 7-13.

Nationwide Mutual Insurance Company. (2012) "Nationwide Statement Regarding Concerns About Hydraulic Fracturing," Press release dated July 13. Last accessed in January 2013 at: http://www.nationwide.com/newsroom/071312-FrackingStatement.jsp.

NaturalGas.org. (2011) "Unconventional Natural Gas Resources," Accessed in January 2013 at http://www.naturalgas.org/overview/unconvent_ng_resource.asp.

Pennsylvania Department of Environmental Protection. (2010) "Landowners and Oil and Gas Leases in Pennsylvania," Fact Sheet, last accessed in January 2013, at http://www.elibrary.dep.state.pa.us/dsweb/Get/Document-91369/8000-FS-DEP2834.pdf.

(C) Southern Regional Science Association 2013. 
Radow, Elisabeth N. (2011) "Homeowners and Gas Drilling Leases: Boon or Bust," New York State Bar Association Journal (November/December).

Robinson Township, et al. v. Commonwealth of Pennsylvania Public Utility Commission, et al. (Docket No. 284 MD 2012). Available at: http://ujsportal.pacourts.us /DocketSheets/CommonwealthCourtReport.aspx?docketNumber=284 MD 2012.

Robinson, Rudy R., III, and Scott R. Lucas. (1998) “Appraising 'Environmentally Challenged' Real Estate for Tax Purposes." Presentation at the Texas Oil and Gas Association Annual Property Tax Representatives Conference, February 23-25.

Rosen, Sherwin. (1974) "Hedonic Prices and Implicit Markets: Product Differentiation in Pure Competition," Journal of Political Economy, 82, 34-55.

Sanders, Michael. (1996) "Post-Repair Diminution in Value from Geotechnical Problems," Appraisal Journal, 64, 59-66.

Taylor, Laura O. (2008) "Theoretical Foundations and Empirical Developments in Hedonic Modeling." In Andrea. Baranzini, José Ramirez, Caroline Schaerer and Philippe Thalmann, eds, Hedonic Methods in Housing Markets, Springer Science + Business Media, LLC: New York, pp. 15-38.

Throupe, Ronald L., Robert Simons, and Chen Huo. (2012) “An Exploration of Hydro 'Fracking' and Real Estate Effects." Unpublished paper presented at the American Real Estate Society Annual Meetings, St. Petersburg, FL, April 18-22.

U.S. Department of Housing and Urban Development. (2007) Valuation Analysis for Single Family One- to Four-Unit Dwellings. Directive 4150.2. Available at http://www.ahacpa.org/ahacpadocs/guides/4150.2.pdf.

U.S. Department of Housing and Urban Development. (2009) "Chapter 9: Environmental Review" of the Multifamily Accelerated Processing. Last accessed December 10, 2012 at http://www.hud.gov/offices/hsg/mfh/map/mapguide/chap09.pdf.

U.S. Government Accountability Office. (2012) "Information of Shale Resources, Development and Environmental and Public Health Risks," September. Last accessed in January 2013 at http://www.gao.gov/assets/650/647791.pdf.

Wilhelmsson, Mats. (2000) "The Impact of Traffic Noise on the Values of Single-family Houses," Journal of Environmental Planning and Management, 4, 799-815. 